\title{
Ibn Hajar Al-Asqalani's Approach Assessing the Transmitter Shia Qualifies the Tsiqah in the Book Tahdzib Al-Tahdzib
}

\author{
Khairil Ikhsan Siregar \\ ${ }^{1}$ Islamic Religious Education \\ State University of Jakarta \\ Jakarta, Indonesia \\ ${ }^{2}$ Student of Doctoral Program at Graduate School \\ Syarif Hidayatullah State Islamic University \\ Jakarta, Indonesia \\ Khairil_siregar@ @unj.ac.id
}

\begin{abstract}
The scholars of critics hadith differ when judging the transmitters by praise respectively which are then categorized in the level of al-jarh and al-ta'deel, then from the commentators the scholars of critics hadith determine the qualifications of the transmeters of hadith. The question explored in this study suggests that Ibn Hajar raised the characteristics of shia surface in the comments of al-jarh and al-ta'deel especially in his work, the book Tahdzib al-Tahdzib, Ibn Hajar ranked al-jarh and $a l$-ta'deel to twelve stages classified six levels for praise alta'deel (praising) and six levels for al-jarh (criticizing). The first rank and followed by the second, third and fourth rank, including the rank categorized by the narrators of traditions that can be used as evidence shari'a. Whereas the narrator of hadith followed by the characteristics of shi'a including the fifth rank is equated with the nature of the narrator who has a wisdom, or that there is an error, or that there is a change of memorization at the end of his life. Praises shia by Ibn Hajar, includes in the levels of al-ta'deel (praising) which are found in the books of Tahdzib al-Tahdzib. Therefore, this study explores the answers to the truth level of praise shi'a being enhanced tsiqah according to Ibn Hajar al-Asqalani.
\end{abstract}

Keywords- Ibn Hajar Al-Asqalani; Transmitter; Shia; Tsiqah; Tahdzib Al-Tahdzib

\section{INTRODUCTION}

The process of transmitting the traditions of the Prophet Muhammad has passed a long history of receiving the full attention of Muslim circles, especially the scholars of hadith to get the traditions of the prophet can be accepted as an evidence shari'a or reject the hadith cannot be made evidence shari'a. Even in the Muslim beliefs, all of the Prophet's hadiths, words, deeds, and decrees are the second source of Islamic teachings after the Qur'an. Thus, the scholars of hadith have tightened to accept the hadith of the prophet especially as it is known in the history of expediting the occupation and the opening of the new hadith is done officially after the instruction of Caliph Umar bin Abdul Azis [1]. The incident of shifin war at the time of the Caliph Ali bin Abi Talib with Muawiyah bin Abi Sofyan who became governor of Syria became a history of slander among Muslims and at that time has influenced the efforts of counterfeiting the traditions of prophets [2]. Because in those days groups who wanted to destroy Islam were a great opportunity for them to utilize the authority of the traditions of the prophets to make false traditions propped up against the prophet.

The slanderous incident is a class that does not like Islam named zidiq people [3], i.e they are people pretending to Islam but actually, they still follow the religion of their ancestors. That is the main reason why scholars of hadith are very careful to accept the hadith from the transmitters of traditions. Then the scholars gave birth to the science of transmitters hadith the science of the only science belonging to Muslims that this science is then divided into two disciplines, the first science of the history transmitters traditions (tarikh al-ruwah) that is the biography of the transmitters and coupled with commentary scholars critic of hadith, the second science of al-jarh wa alta'deel is the science to know the inherent attributes of the transmitters of hadiths good or bad so that the hadith that narrated can be accepted or rejected. The scholars of the hadith critics differ when judging the transmitters by expressions or praises respectively which are then categorized in the level of al-jarh wa al-ta'deel (maratib al-jarh wa al-ta'deel) then from the commentators of hadith critics determine the qualifications of transmitters hadith. This makes the scholars of hadith critics divided into three categories: hard, moderate, and subtle.

The Shi'ite narrator in the view of the hadith scholars is incorporated into the heresy group. Junaid Ashraf explains that heresy is one of the qualities that injure the justice of the hadith narrator [4]. However, the actions of the hadith scholars do not all apply to the extreme not to narrate the hadith of the group claimed to be a follower of the heresy or to strongly reject the transmission of traditions from the heresy. Hadith scholars still treat them fairly and wisely in justifying their traditions. For the main reason in the opinion of the hadith scholars if they do not serve the transmission of hadith from the heresy group it will be much missing the hadiths of the Prophet who are not 
inherited to the Muslims. In the Hadith scholars' agreement that the class of heresy is divided into two parts, first: "yukaffiru bi bid'atih" means a man who is disbelieved because of his heretical heresy, for denying the established religious matters and making religious matters new to Islam. As from group alrawafidh al-ghalat. Secondly, the heresy group: laa yukaffiru bi bid'atih means a person who does heresy but not to make it a kafir, like the group of khawarij and al-rawafidh which is not al-ghalat [5].

Ibn Hajar al-Asqalani also explains the division of heresy in his book "al-Nukhbah" that the bid'ah is divided into two parts whether it is bid'ah mukaffirah or bid'ah mufassiqah. The meaning of bid'ah mukafirah that the meaning does not mean to harm a narrator of hadith because only he did heresy adds and reduces the teachings of Islam. So understanding the term mukaffirah according to Ibn Hajar al-Asqalani is not a pagan who openly deny or reject the teachings of Islam. The heresy of mufassiqah is a wicked deed which leads to fanaticism to what he believes and then invites others, or is fanatical but merely shows his excessive love to someone but does not invite others to follow him. According to Ibn Hajar al-Asqalani the narrator of hadith which only bid'ah either mukaffirah or mufassiqah the transmitter acceptable [6].

The book Tahdzib al-Tahdzib is the work of Ibn Hajar alAsqalani which became one of the books of al-jarh wa alta'deel which composed transmitters hadith from the hadith books al-sittah as the most recent book of al-jarh wa al-ta'deel and the famous book as a reference to transmitters hadith in academic circles specifically for the study of transmitters hadith. The book Tahdzib al-Tahdzib in this study is the source for exploring comments or phrases and praises al-jarh wa alta'deel especially Ibn Hajar al-Asqalani's comment, hence the problem in this study how praises tsiqah juxtaposed with praise shia whereas in the qualifications of the narrators who accepted the hadith, i.e. the fair narrator means preserved from the bad or far from the act of heresy. So the problem restriction in this research is what approach used by Ibn Hajar al-Asqalani to determine the narrator of shia as a narrator tsiqah/reliable narrator.

\section{Methodology}

This research uses a qualitative approach that is, a research procedure that produces descriptive data in the form of words, writings, or oral from the observed people [7]. Qualitative research is also the effort to build the theory from the results of research. This research will focus on library research, namely, using the sources of literature in discussing the principal and sub-issues that have been formulated. The method used in this research is as follows:

\section{A. Approach}

Because of the subject of this study, it revolves around the science of al-jarh wa al-ta'dīl a science of Islam through a long period of time from the time of prophethood to the third and fourth centuries, and then born the theoretical rules in the science of al-jarh wa al-ta'dill resulting from the efforts of scholars of hadith critics in order to reveal the credibility of the narrators of hadith. Then the first method taken in the data collection step is the historical method.

\section{B. Data Source}

In the process of collecting data, this research is more based on the study of manuscripts or documents. The data sources used consist of primary and secondary. Primary source in the work of Ibn Hajar al-Asqalani, the book Tahdhib al-Tahdhib and Taqrib al-Tahdzib. Secondary data sources are texts or other books related to this research, books of hadith, journals, and papers.

\section{DISCUSSION}

\section{A. The meaning of al-Jarh wa al-ta'dil}

The science of al-jarh wa al-ta'dil when examined in terms of language consists of two words taken from the Arabic, aljarh verbs form the noun comes from the verb: jaraha-yajrahu [8] means to injure, or injure some body means to hurt. The state of injury here in physical as well as non-physical form, such as bodily injuries exposed to sharp objects so that the blood flows physical or like the wound of the heart by hearing the rude words of a person non-physical.

The meaning of the word al-jarh in language can also be interpreted to some meaning:

1) Acts: Reinforced with meaning in the Qur'anic verse: QS. Al-An'am: 6:60, Al-Jatsiyah: 45:21, Al-Maidah: 5:4. Imam al-Iji interpret the word: jarahtum, ijtarahu, al-Jawarih in the verse is interpreted deeds.

2) Ibn Mandzur explains in the oral dictionary al-'Arabi

3) Injuries: Injuries caused by tools that can hurt either a knife, a sword, or a tool of war, such as a spear, etc. Al-juruh wound is strengthened by the meaning of the verse, QS. AlMaidah: 5:45.

4) Disappearing of justice: Ibn Mandzun said: "al-Hakim al-syahid idza 'utsi fihi' ala ma tasquthu bihi 'adalatuh min kidzibin wa ghairih", meaning Al-Hakim refuses a witness if evidence has been shown to weaken justice, such as lies and others.

The word al-ta'deel comes from the root of the verb 'adala, the word al-'adl means a good trait embedded in the soul making itself consistent/mustaqim versus the al-jaur bad nature/ugliness. Sa'id bin Jubair explains the meaning of $a l^{-}$'adl to four characteristics:

- al-'adl in establishing the law: Reinforced by the meaning of the verse in QS. Al-Nisa': 3:58.

- al-'adl in speech: Reinforced by the meaning of the verse in QS. Al-An'am: 6:152.

- al-'adl in issuing fidiah: corroborated by verse in QS. Al-Baqarah: 2:152.

- al-'adl in the act of shirk: Corroborated by verse in QS. Al-An'am: 6:1.

The word al-jarh in terminology includes two meanings; jarh al-syahid and jarh al-ra wi. Al-Jurjani explains the intent 
of the jarh al-syahid the wicked deeds that impose the nature is so rejected to be a witness but not included in the act of violation shari'a, for example the actions of lies, usury, spreaders of slander. In these case scholars, there are two opinion, first reject the witness of the wicked taken the proposition of verse: QS. Al-Nur: 24:4, Meaning: "..., and do not accept their testimony forever. And they are the wicked". The second opinion, accepting the testimony of the wicked who have repented by postulate the verse QS 24:5, Meaning: "except for those who repent afterwards and repair him, then Allah is Forgiving, Most Merciful". Amin Abu Lawi explains that the first opinion does not accept their greater testimony, because it is the right to possess God alone and most scholars do not accept a wicked testimony lying once just to hatch the name of the Messenger of Allah even if that person really repents $[9]^{1}$. The main reason for the mocking of the testimony for the injury of a witness is that he is a wicked person and because the characteristics of a witness must be fair and the argument of the verse QS. Al-Thalak: 65:2. It means: "... witness with two fair witnesses among you". The argument for the rejection of a wicked witness is taken QS. Al-Maidah: 5:107: "If it is known that the two (witnesses) make sin, then two others of the rightful heirs are closer to the one who died (advance demands) to replace...".

The second is that jarh al-rawi terminologically expresses the nature to the narrator who can damage his justice or destroy his rote power (dhabath) or both traits that rejected his hadith and is unacceptable for his transmission [9] ${ }^{2}$. Shaykh Manna Al-Qaththan defines the meaning of al-jarh according to the term is the appearance of the nature of a transmitter who can overthrow his justice, and destroy his rote and memorizing, causing him to fall, or to weaken it so that it is rejected [10].

The word $a l$-ta'deel is in terms of the nature which appears in the transmitters of the traditions that make its history acceptable. It is more clear that accepting or abandoning or unacceptable to the history of the hadith is the aim of both alta'deel and al-jarh, both of which have many qualities which reveal to the two variables, the phrase or praises appear in the narrator of the hadith, consistent with those traits and preserved from the ungodly traits, plus possessing a strong memorizing nature, and bringing the true tidings of this is the full variables of al-ta'deel.

'Ajaj Al-Khathib, summarizing the science of al-jarh wa alta'deel is a science that discusses the situation of the transmitters of hadith in terms of the acceptance or rejection of their narrations [11]. Amin Lawi, defines the science of al-jarh wa al-ta'deel discusses the rules which are the cornerstone of establishing the qualifications of the narrator of the hadith from the nature of al-jarh as well as from the nature of al-ta'deel which is conveyed through the expression-phrase or praises aljarh wa al-ta'deel [9] ${ }^{3}$. Abu Hatim Al-Razi, in the preamble of his book al-jarh wa al-ta'deel defines the science of al-jarh wa al-ta'deel, that is a science which discusses al-jarh and alta'deel the narrators of hadith by using certain praises and

\footnotetext{
Abu Lawi, Amin., pp.64

2 Abu Lawi, Amin., pp.71

${ }^{3}$ Abu Lawi, Amin., pp.72
}

discuss also about the levels of the praises and the science of al-jarh wa al-ta'deel this is one branch of transmitter science hadith [12].

Abu Amru bin Al-Shalah explains that the requirement for the narrator to be accepted by his hadith must be a Muslim, adult, 'aqil, preserved from the things that cause wickedness, and which destroy grants, intelligent is not negligent, strongly memorize if he conveys from his memorizing, or memorized his book is accurate if he memorizes from his book, even though he narrated in the meaning required to understand the perfect understanding that he told [13]. In addition, the main one in determining the criterion of a narrator of the hadith so that his history is accepted, that is to say, must have the following two qualities: a narrator of hadith has the nature of 'adalah and dhabath [14]. The meaning of 'is as described above, preserved from the wicked nature. Nur al-Din 'Atir, explaining the nature' is that it includes: Islam is otherwise rejected, adult because in adulthood it has received the mandate of distinguishing responsibilities and can die the forbidden acts, sensible and intelligent so as to be true and able to speak, fear and leave the sinful great, avoidance of continuous small sin, have a noble nature and keep it from things that lowered his self-esteem [13].

As for the meaning of dhabath, Ibn Manzur affirms the nature that controls something and binds it. Al-Laisi, gives the meaning of dhabath to something and is never separated from him anymore $[9]^{4}$. As for the characteristics of dhabath the power of memorization and dexterity rote memorization. The clarity of the memorizing power keeps what is heard or is always able to perceive the power of memorize and deft memorizes it whenever it is needed, Ibn Sayyidah said: "Memorize the law forget." And the meaning of the rote memorization of consciousness and the power of concentration is not preoccupied with anything disturbing its concentration, while forgetfulness, and doubt is the opposite of the meaning of yaqzhah/concentration. It also applies when listening, memorizing hadith tahmmul and transforming hadith to others $a l$-ada' must yaqzhah/ concentration strong not forgetful and hesitant in memorization.

\section{B. Method, and Maratib Al-Jarah wa Al-Ta'dil}

The method here means that the scholars of the hadith, especially those specialists in this field of scholars critic in attempting to establish the laws and rules used in doing al-jarh and al-ta'deel very varied. Sometimes scholars of Hadith critics agree on judging the personality of al-particular narrator and sometimes differing opinions. In addition, sometimes a critic also has different judgments about a person. So with the method that has been established scholars critics of hadith, is expected to produce a more objective assessment.

Here are some rules or as a method of settlement established by the critics, if there is any difference in the judgment of a narrator of the hadith. Indeed there have been many theories or solutions offered by scholars to resolve disagreements or disagreements between one scholars and other scholars in terms of the judgment of a transmitter. So

\footnotetext{
${ }^{4}$ Abu Lawi, Amin., pp.102
} 
when read in the hadith books a lot of rules agreed by scholars critics hadith more thirty-two rules $[9]^{5}$. Among the most proposed rules presented in this study are six theories that will be described:

1) Al-Ta'dil Muqaddamun 'ala al-Jarh: This means that if a narrator is praised by a scholar critic of hadith and judged by other critics, the precedence is good. Because the nature of the narrator hadis is praiseworthy, whereas reprehensible nature is a trait that comes later. So the dominant trait is commendable.

2) Al-Jarhu Muqaddamun 'ala al-Ta'dil: This means that if a person is judged by a scholar critic of hadith and judged to be praised by other critics, then the precedence is the nature of the assessed reproach. The reason is because the cleric critics who expressed more personal misinterpretation of the narrators who reproached. Then the basis for praising a narrator is the good conjecture of the scholas criticers personal and the good conjecture must be defeated if there is evidence of the loneliness possessed by the narrator in question. Among the scholars of criticers hadith, fiqh scholars, and scholars of the jurisprudence of many who embraced the theory. In this case, many scholar criticer also demand the proof or explanation that is the background to the lucidity expressed against the narrator.

3) Idha Ta'aradha al-Ja rihu wa al-mu'addilu fa al-hukmu li al-Mu'addil illa idha tsubita al-jarhu al-mufassar: That is, if there is a contradiction between comments/criticisms that praise and who criticize, then that should be won is a comment that praises, unless the criticism is criticized with an explanation of the causes. In this case if a narrator is praised by a particular critic and criticized by other criticers, then basically what should be won is a compelling commentary, unless a reproach criticism accompanies an explanation of the proof of the narrator's narration. Criticers who are able to explain the causes of the history of intelligence are judged to know more about the person of the narrator than the critic who only praises the same narrative. Scholars mayority said that the explanation of the proposed liturgy should be relevant to the research effort. Then if the critic who praises has known the reasons for the descriptions of the descriptive narrative and he perceives that the causes of the lameness are irrelevant or absent, the criticisms that should be chosen. And so on.

\section{LEVEL OF EXPRESSION, LAFAZ AL-JARH AND AL-TA'DIL}

The hadith narrator who transforms the hadith is not all alike in one level in his memorization, science, and in the synthesis. There is hafiz mutqin which is no doubt its reliability. There is a lower dhabith and memorization. There is also a bit of a mistake or often forget and wrong, although it has a fair and honest nature. There is also a smuggling into the group of hadith scholars, but God unmasked it through the hands of the eminent critic. The judges 'critics' judgments reach us through classical works, such as al-Duh'afa 'al-Bukhari and al-Dhu'afa' by al-Nasa'i. The first to express the phrase and praises al-jarh and al-ta'deel is Abu Muhammada Abdurrahman ibn Abi Hatim al-Razi who died in $327 \mathrm{H}$ [15].
Such is the condition of the narrators, some higher than others. Thus the expression and praises figures al-jarh wa al-ta'dil is multilevel, each of which shows the position of the narrator called the phrase or praise.

And different scholars of hadith critics have argued about the number of levels of al-jarh and al-ta'deel, some of them three levels, four levels, and six levels, of all the scholars of hadith critics do not make much change when determining the level of al-jarh as well al-ta'deel is still in the range set by Abu Hatim Al-Razi. Ibn Shalah followed by Al-Nawawi, Al-Zahabi followed by Al-'Iraqi there is little change and Ibn Hajar alAsqalani followed by the student of Al-Sakhawi makes the level of al-jarh and al-ta'deel six levels [16]. As described below "level al-Ta'dil".

1) Level al-Ta'dil compilled by Abi Hatim Al-Razi:

- First level: tsiqah, mutqin, tsabat.

- The second level: Shaduq, mahalluhu al-shidqi, la ba'sa bihi.

- Third level: shaykhun, yuktabu hadisuhu, wa yunzharu fihi.

- Fourth level: shaleh.

The explanation of the above description of al-ta'dil above that Abi Hatim wants those who occupy that first level are all scholars of the hadith's critics of concern for the existence of this science, and distinguish them by the level of the narrators of tradition, such as lafaz used when mention the name of a scholar of hadith critic with lafaz, hujjah for example when scholars ask Al-Ajra Aba Daud from Sulaiman bin Binti Syarhabil then said: is he a hujjah ? Abu Daud said: "al-Hujjah Ahmad bin Hambal". And another example, listening to the words of Uthman bin Abi Syaibah to Ahmad bin Abdullah bin Yunus: "tsiqah wa laisa bi hujjah", and Ibn Main's words about Muhammad bin Ishaq, "tsiqah wa laisa bi hujjah". Then for the second and third levels belong to another group of fair narrators.

\section{2) The level of al-Ta'dil compiled by Ibn Shalah:}

First level: tsabat, or hujjah, hafiz or dhabith.

Second level: shaduq, mahalluhu al-shidiq, or la ba'sa bihi.

Third level: Shaykhun.

Fourth level: shalihul Hadith.

The explanation of the level submitted by Ibn Salalah, the rank is not much different it's praises with Abi Hatim bin Shalah explained in the second rank that his history with praise yunzharu fi hadishim cannot be made evidence and what else when narrated history's hadith only he himself then very strong to reject his hadith. While the third rated praise shaykhun according to Ibn Shalah its hadith can only be written only and the quality is lower than the second rank [9] ${ }^{6}$.

3) Rank of al-Ta'dil sorted by Al-Zhahabi:

- First level: hujjah tsabat, hafizh tsabat, tsiqah mutqin, tsiqah tsiqah.

\footnotetext{
${ }^{6}$ Abu Lawi, Amin., pp.226
} 
- The second level: tsiqah shaduq, la ba 'sa bihi, laisa bihi ba'sun.

- Third level: Mahalluhu al-shidiq, jayyidul hadith, shalihul Hadith, sayikhu wasathun, shaykh hasanul hadith, shaduq insyaallah, shawaileh.

The explanation from Al-Zahabi on the level of al-ta'dil above can be found in his book "dzikrun man yu'tamad qauluhu fi al-jar wa al-ta'dil", the intent of lafaz "al- 'adl alhujjah" is said to be like a strong and healthy young man, and lafaz "tiqah shaduq", he has a good man and middle power, and lafaz "shaduq or la ba'sa bihi", he like a man between thirty and fifty healthy years, and praise "al-shaduq al-dzi fihi lainun", he makes me like a healthy person but in part of his body there is a sick, such as itching in the head [9] ${ }^{7}$.

4) Level al-Ta'dil sorted by Al-'Iraqi:

- First level: tsiqah tsiqah, tsiqah tsabtun.

- The second level: tsiqah, tsabtun, hujjah, hafizh, dhabith.

- Third level: laisa bi ba'sun, shaduq, ma'mun, khayyar.

- Fourth Level: Mahalluhu al-shidiq, laisa baidan 'un alshidqi, shaykh wasath, wasath, shaykh, shalihul Hadith, maqaribul hadith, jayyidul hadis, syikhu wasathun, shaykh hasanul hadis, shawaileh, shaduq insyaallah, a'sunarju 'an la fihi ba'sun.

5) Rank of al-Ta'dil sorted by Ibn Hajar Al-Asqalani:

- First level: Companion because of the high position, noble

- Second level: Autsaqa al-nasi, tsiqah tsiqah, tsiqah hafizh.

- Third level: tsiqah, mutqin, tsabat, adlun.

- Fourth level: shaduq, laisa bihi ba'sun.

- The fifth level: shaduq siul hifzhi, shaduq yahim or lahu auham or yukhthi ', or taghayyara fi akhirih incorporated heresy, such as qadr, syi'ah, nashab, irja', al-tahajjum with explanation of her bid'ah condition

- Sixth level: man laisa lahul Hadith illa qalil, lainul Hadith.

To the level of al-jarh is not described in the study because the focus of his research is on the approach/method of Ibn Hajar Al-Aqalani on the position of lafaz al-ta'adil followed by the praise of the heresy, shia in the book "Tahdhi al-Tahdhibi", as well as the book Taqrib al-Tahdhib.

\section{THE SHIAIST SHIA QUALIFIES THE TSIQAH IN THE BOOK "TAHDZIB AL-TAHDZIB"}

The question explored in this study suggests that Ibn Hajar raised the characteristics of shia surface in the comments of aljarh and al-ta'dil especially in his work tahdzib al-tahdzib and taqrib al-tahdzib. While the character of shia one of the names

\footnotetext{
${ }^{7}$ Abu Lawi, Amin., pp.227
}

of the heresy that disturb the sensitivity of the Muslim community ahl sunna because of its relation with the history of the birth of their shia group that came out of the tradition of $a h l$ sunna, such as fanatics to Ali bin Abi Talib or transcend the belief of ahl sunna, the descendant of Ali ibn Talib who became the ahl bait of the temple, likened his position to Muhammad Rasullah both received revelation and believed.

For comments or lafaz al-jarh and al-ta'dil by Ibn Hajar, insert in the levels of al-ta'dil (good personality traits) which Ibn Hajar ranked al-jarh and al-ta'dil to twelve levels are classified six levels for praise al-ta'dil and six levels for aljarh. The first rank of friends described because of their glory is all fair and dhabith, and followed by the second, third and fourth rank, including the rank categorized by the narrators of traditions that can be used as evidence Shari'a. Whereas the narrator of the traditions followed by the characteristics of shah'ah including the fifth rank is equated with the nature of the narrator who possesses the waham/auham, or that there is an error, or that there is a change of memorization at the end of his life.

It is very different from the levels of al-jarh and al-ta'dil that critics of hadith before Ibn Hajar, like Al-Zhahabi strongly emphasized to be concerned that the rank among transmitters hadith was occupied by scholars of hadith critics, which is made a difference with other fair narrators of tradition. The phrase and praise conveyed by the earlier cleric critics, from Abu Hatin Al-Razi, Ibn Shalah, Al-Zhahabi, and Al-'Iraqi is much less qualified than the praise conveyed by Ibn Hajar alAsqalani. Because when compared to first level lafaz only Abi Hatim using lafaz tsiqah and while lafaz tsiqah for Ibn Hajar was ranked third. The study of the phrase and lafaz of the scholars of hadith critics is a major and important concern as a source of study in the science of al-jarh wa al-ta'dil, which then proceeds with their opinion establishing laws and rules which, in the opinion of scholars critics of hadith to establish the qualifications of narrators of hadith.

\section{ANALYSIS OF THE EXAMPLE OF THE NARRATOR SHI'A IN THE BOOK OF TAHDZIB AL-TAHDZIB}

\section{A. Abana bin Taghlib Al-Kufi}

Some commentators of the critics, Yahya, Ahmad, Abu Hatim, and Al-Nasai 'said: Abana is a tsiqah of hadith narrator. Then added Abu Hatim he is shaleh, Al-Juzjani said: he narrator deviated blasphemous shamelessly, Ibn 'Addi said: he has a generally hadith script of shaheh and the one who narrates from him is a tsiqah and he the righteous in the narrations of his hadith even though he is shia and shalihun in narrating hadith. Then Ibn Hajar commented on the saying of Al-Juzjani, saying: hasty words, showing not knowing many of shia. The mutaqaddimin scholars define them the shia group love Ali bin Abi Talib and glorifies it from Uthman bin 'Affan, who lost and actually opposed the wrong, they glorified the two previous caliphs of Abu Bakr and Umar, even if some of them glorified Ali bin Abi Talib after the Messenger of Allah with the supreme confidence of religion and the spirit of his life then no history of hadith will be rejected moreover they have no element to force people to follow him. However, unlike the scholars mutaakhirin defines the shah'ah group they are al- 
rafidhah only, then it is not accepted the history that comes from al-rafidhah al-ghali. 'Ajlan said: Aba na bin Taghlib say hadith to us, he is domiciled in Iraq strong people worship and tsiqah also. Al-Hakim said about Abana bin Taghlib after he criticized it and entered it in his book istidrak then said the real Abana tsiqah hadith narrator but very fanatic with shah'ah. Ibn Sa'ad said: Abana a tsiqah, and Ibn Hibban included Abana in the narrated narrators of hadith. Al-Azdi said: Abana a fanatic with shi' $a$ but I think he is a narrator who has no problem [17].

\section{B. Abdul Malik bin Sallamah al-Hanafi, Abu Sallamah al- Kufi}

Comment of the critics, Ibn Main said: tsiqah, Abu Hatim and Abu Daud said: laa ba'sa bihi, Ibn Khirasy said: laisa bi ba'sun min al-shi'a, Ibn Himban said: tsiqah, Ibn Hajar responded to the comment that Abdul Malik bin Sallamah can not be used as a proof of his narrated. Then the results of the findings of two books Tahdhid al-Tahdhib and Taqrib alTahdhib, Ibn Hajar said that Abdul Malik bin Sallamah is tsiqah shia ranked seventh [18].

From the description is recorded in the book Tahdzib alTahdzib. Muhammad 'Awamah explains that from the results of his criticism of the two books of Ibn Hajar's "al-tahdzib" and "taqrib", he first critics that in the writings in the preamble section of the book that the words of a third of the two books he summarized by al-Miziand Mughlathaya are the editing error of the publisher and in fact two-thirds are deleted by Ibn Hajar which he adds to his thickness closer to the original. The second discovers the inconsistency of Ibn Hajar determining the qualification of Abana bin Taghlib with what in $a l$-tahdzib approves him tsiqah despite his fanatics with shah'ah but in book "taqrib" mentions him a tsiqah but because fanatics with shah'ah entering it in the seventh rank of al-jarh wa al-ta'dil. This means that the provisions of the rankings presented by Ibn's twelve-level stages are six levels of al-ta'dil (good personality) and six levels for al-jarh (ugly personality), it can be set in the category of justice according to Ibn Hajar weak because of his bigotry with shah'ah even though his dhabith is good but he does not get tsiqah qualification. Because of the argument of tsiqah when a narrator of hadith has two traits as a condition of a narrator can be accepted his history and can be made evidence shari'a, that is fair and dhabith.

\section{CONCLUSIONS}

Ibn Hajar al-Asqalani when viewed from the history of the compilation of the book Tahdzib al-Tahdzib is recorded as the last book which criticizes transmitters hadith from scholarly side al-jarh wa al-ta'deel and he compiled again the latest book of him does not come out of the contents of the books al-jarh wa al-ta'dil earlier. And because of the intelligence he possesses and the ability to memorize many of the hadiths he has removed two-thirds of the two works of Al-Mizi and Mughlathaya because according to him many things have not been explained and less important then he can add the number of writings of nearly two books in the rearrangement. Then the result of the comment about Ibn Hajar who praise or the expression of a narrator hadis tsiqah tasyayyu or tsiqah shah'ah turned out after research by raising one of the narrators tsiqah raised in this study found the inconsistency in setting the position of a narrator from the class bid'ah, such as shah'ah but tsiqah in the rank that should be ranked fifth, will be found in the example he positioned the seven level, meaning that his qualifications have been positioned very weak.

\section{ACKNOWLEDGMENT}

This Research Doctoral Dissertation is funding by Ministry of Research, Technology, and Higher Education, Directorate General of Research Strengthening and Development, Directorate of Research and Community Service, Republic of Indonesia, Funding Year 2018.

\section{REFERENCES}

[1] Abu Zah, Muhammad Muhammad., al-Hadith wa al-Muhaddithin, Cairo: al-Maktab al-Taufiqiyyah, 1984, pp.244.

[2] Lalani, Arzina R., Early Shi'i Thought, London: I.B. Tauris \& Co Ltd 6 Salem Rd, 2004, pp.3.

[3] Jabali, M. Fu'ad., Friends of the Prophet Who, Where, and How, Jakarta: Mizan Publika, 2010, pp.41.

[4] Iqbal Ahmad, Junaid Ashraf., al-'Adalah wa al-Dabth wa Atsaruhuma fi Qabuli al-Ahadith au Radduha, 2006, pp.261.

[5] Ma'arif, Majid., Tarikh 'Ulumul al-Hadis, translated by Abdillah Mushthafa, Sejarah Hadis, Jakarta: Nurul Huda, 2012, pp. 242.

[6] al-Tahan, Mahmud., al-Manhaj al-Hadith fi Mustalh al-Hadith, 2004, pp.82.

[7] Molong, Lexy., Metodologi Penelitian Kualitatif, Bandung: PT. Remaja Rosdakarya, pp.14.

[8] Ibn Mandzur., Lisan al-Arabi, Beirut: Dar Shadir, 1990, pp.423.

[9] Abu Lawi, Amin., Ilmu Ushul al-Jarh\} wa al-Ta'deel, Saudi Arabiyyah: Dar Ibn ‘Affan. 1990.

[10] Al-Qațtan, Manna., Pengantar Studi Ilmu Hadis, traslator Mifdhol Abdurrahman, Jakarta: Pustaka Al-Kautsar, 2009, pp.82.

[11] Al-Khathib, Muhammad 'Ajaj., Ushul al-Hadis, Lebanon: Dar al-Fikri al-Hadith, 1967, pp.261.

[12] Abu Muhammad Abdurrahman bin Abi Hatim Al-Razi, al-jarh wa alta'deel, Beirut: Dar al-Kutub al-'Ilmiyyah, 1952, pp.3.

[13] 'Atir, Nur al-Din., Manhaj al-Naqdi fi 'Ulum al-Hadis, Damascus: Dar al-Fikri, 1981

[14] Salalah, Ibn., directed by Nur al-Din 'Atir, Muqaddimah Ibn Shalah fi' Ulum al-Hadis, Damascus: Dar al-Fikri tt, pp.104.

[15] Al-Khathib, Muhammad 'Ajaj., Ushul Al-Hadis, translated by H. M Qadirun and Ahmad Musyafiq, Ushul Al-Hadis, Jakarta: Primary Media Style, 2007, pp.246.

[16] Hamadah, Faruq., Al-Manhaj al-Islami fi al-Jarh wa al-Ta'dil, Cairo: Dar al-Salam, 2008, pp.299.

[17] al-Asqalani, Ibn Hajar., Tahdhib al-Tahdhib, Berut: Maktab Tahqiq alTurat fi Muassasah al-Risalah, 1995, pp.8

[18] 'Awam, Muhammad., Taqrib al-Tahdhib, Siria-Halab: Dar al-Rasyid.tt, pp.376. 